Board of Governors of the Federal Reserve System

International Finance Discussion Papers

Number 705

August 2001

AN EMPIRICAL COMPARISON OF BUNDESBANK AND ECB MONETARY POLICY RULES

Jon Faust, John H. Rogers, and Jonathan H. Wright

NOTE: International Finance Discussion Papers are preliminary materials circulated to stimulate discussion and critical comment. References in publications to International Finance Discussion Papers (other than an acknowledgment that the writer has had access to unpublished material) should be cleared with the author or authors. Recent IFDPs are available on the Web at www.federalreserve.gov/pubs/ifdp/. 


\title{
AN EMPIRICAL COMPARISON OF BUNDESBANK AND ECB MONETARY POLICY RULES
}

\author{
Jon Faust, John H. Rogers, and Jonathan H. Wright*
}

\begin{abstract}
We estimate a monetary policy reaction function for the Bundesbank and use it as a benchmark to assess the monetary policy of the ECB since the launch of the euro in January 1999. We find that euro interest rates are low relative to this benchmark. We consider several possible reasons for this, including the divergence between core and headline inflation, mis-measurement of the output gap, inflation having turned out to be higher than could have been foreseen by the ECB and the possibility that the ECB is focusing only on macroeconomic conditions in a subset of member countries. We argue that none of these potential explanations alone can account for the difference between recent interest rates and our estimated Bundesbank benchmark. Our results suggest that the reaction function of the ECB features a high weight on the output gap relative to the weight on inflation, compared to the Bundesbank.
\end{abstract}

Keywords: Taylor Rule; Monetary Policy; European Central Bank; Bundesbank; Inflation.

* Division of International Finance, Board of Governors of the Federal Reserve System. We are grateful to Joe Gagnon, Mark Gertler, Dale Henderson and Linda Kole for helpful comments. The views in this paper are solely the responsibility of the authors and should not be interpreted as reflecting the views of the Board of Governors of the Federal Reserve System or of any person associated with the Federal Reserve System. 


\section{Introduction}

When the national central banks of the 11 members of Europe's Economic and Monetary Union (EMU) handed over control of monetary policy to the European System of Central Banks (ESCB) in January 1999, it began an experiment in central banking without precedent. A common monetary policy for all EMU countries is now formulated by the supra-national governing council of the European Central Bank (ECB), which consists of a six-member executive board and the heads of the national central banks.

Long before January 1999, observers worried about precisely how a European central bank would function. DeGrauwe (1997) noted that there is very little economic incentive for low-inflation countries to join in monetary union with high-inflation countries, and discussed how this should influence design of the ECB statutes. One way to give low-inflation countries like Germany an incentive to join EMU it was felt, would be to create a supra-national monetary authority that is at least as hardnosed as the Bundesbank. As DeGrauwe (1997) noted, "If the German monetary authorities are forced to accept EMU, they will probably insist on having an ECB that gives an even higher weight to price stability than the Bundesbank does today".

DeGrauwe (1997) and Gros and Thygesen (1998) emphasized that much of

what the low-inflation countries (most notably Germany) insisted upon was indeed written into the ECB statutes, as spelled out in the Maastricht Treaty. These authors 
argued that the ECB statutes gave even more emphasis to price stability than the Bundesbank did at the time. This could be seen, first, in the clear and explicit statement in the treaty that "The primary objective of the ESCB shall be to maintain price stability." An important corollary feature is that the treaty provides the ECB with a certain degree of independence, which of course is seen as necessary to ensure that budget deficits of the national and European governments will not be financed by printing money. It has even been noted that, because the ECB operates above and beyond the reach of any single national government, it is arguably more independent than the Federal Reserve. DeGrauwe (1997, p. 175) summed it up as, "The language used by the drafters of the statutes of the ECB is tougher on inflation and political independence than the statutes of the Bundesbank." Meanwhile, Gros and Thygesen (1998, p. 493) asserted that, "From an institutional point of view, one would expect the monetary policy of the ECB to be at least as good in terms of price stability as the Bundesbank."

While these and other authors described the importance of the ECBs institutional design and the Maastricht convergence criteria on inflation, budget deficits, etc. in generally optimistic tones, they also reasoned that a prospective ECB might well be unwilling or unable to keep euro area inflation as low as the Bundesbank kept German inflation. The list of concerns included technical details like the existence of some wiggle-room in the statutes, potential conflicts with exchange rate policy which 
was to be left to the political authorities, and initial ambiguity over which price index would be targeted. These authors also recognized that the "anti-inflation lobby" in most EMU countries is not as intense as it is in Germany, so that a governing board dominated by representatives of national interests might produce too much inflation (von Hagen and Suppel, 1994). Again to quote DeGrauwe (1997, p. 178), "[The ECB board members] may, therefore, act differently than the individuals sitting on the board of the Bundesbank, even if the statutes of the ECB have been copied from the Bundesbank statutes."

In this paper we study the monetary policy of the ECB, and compare it with a simple empirical representation of the monetary policy of the Bundesbank prior to 1999. Many authors have considered the estimation of monetary policy rules that relate the interest rate to inflation and the output gap, known as Taylor rules, both for the United States and for other countries (see e.g. Taylor (1993), Judd and Rudebusch (1998) and Clarida, Gali and Gertler (1998)). We compare the behavior of the Bundesbank with that of the ECB by constructing a simple counterfactual experiment. We estimate the monetary policy reaction function of the Bundesbank, on data prior to 1999. We then take the estimated parameters from this reaction function and use these to predict the interest rate that the ECB would be setting, were it to behave like the Bundesbank, but focusing on euro area data rather than German data. 
Some monetary policy reaction functions estimated in the literature are backwardlooking in the sense that they relate the interest rate to current or lagged values of inflation and the output gap (e.g. Taylor (1993)). More recently, forward-looking reaction functions have been estimated. These relate monetary policy to expected future economic conditions, typically $9-12$ months ahead, as this is the lag with which monetary policy is generally thought to affect the economy. Clarida, Gali and Gertler (1998) estimate monetary policy rules of this sort for a number of countries and it is these monetary policy rules that we consider in this paper.

Our main result is that euro area interest rates have been considerably lower than would be predicted by the Bundesbank's estimated reaction function. We consider several possible reasons for this (under the assumption that the ECBs policy reaction function is the same as the Bundesbank's), but find that none is entirely satisfactory on its own. In general, the path of interest rates since the inception of the ECB would only be consistent with our empirical representation of the Bundesbank's behavior if the ECB generally forecast euro area inflation to be below 1 percent or if the true output gap were 15 percentage points below our estimate. These do not seem to be reasonable magnitudes over this time period. Thus, an important part of the explanation for our empirical finding may be that the reaction function of the ECB features a high weight on the output gap relative to the weight on inflation, compared to the Bundesbank. 
Our work is closely related to recent work by Alesina et al. (2001) and Gali (2001), who compare the monetary policy of the ECB with a benchmark monetary policy rule. Unlike in the present paper, the monetary policy rule in those papers is not estimated from the data and it imposes a zero coefficient on the output gap. However Alesina et al. and Gali find, as we do, that euro area interest rates are generally lower than the monetary policy rule would predict.

The plan for the remainder of this paper is as follows. The next section describes the construction and estimation of a monetary policy rule for the Bundesbank. Section 3 assesses ECB behavior relative to this benchmark, while section 4 concludes.

\section{Monetary Policy Reaction Functions}

The monetary policy rule that we estimate for the Bundesbank follows Clarida, Gali and Gertler (1998), among others. It is forward-looking, and incorporates interest rate smoothing. Specifically, the interest rate, $i_{t}$, depends on the interest rate in the previous period and the target interest rate, $i_{t}^{*}$, so that

$$
i_{t}=\rho i_{t-1}+(1-\rho) i_{t}^{*}+\varepsilon_{t}
$$

where $\varepsilon_{t}$ is an i.i.d. zero mean error term. Smoothing interest rate changes might be rational for a central bank in a learning model, or might result from a fear that abrupt changes in interest rates would be too disruptive to bond and equity markets. 
It is, in any event, a ubiquitous feature of central bank behavior. Meanwhile, the target interest rate satisfies the equation

$$
i_{t}^{*}=\alpha+\beta E_{t}\left(\pi_{t+n}\right)+\gamma E_{t}\left(y_{t}\right),
$$

where $\pi_{t}$ is the year-on-year inflation rate and $y_{t}$ is the output gap (a positive gap implying output above potential). The inflation rate being targeted is $n$ periods in the future, so the monetary policy rule is forward-looking. If the parameter $\beta$ is greater than one, an increase in inflation causes the real interest rate to rise. If this parameter is less than one, the system is not stable and self-fulfilling bursts of inflation are possible (see, e.g., Henderson and McKibbin (1993)).

This kind of monetary policy reaction function indicates that the central bank is targeting inflation (or forecast inflation) but that it is doing so with at least some separate attention paid to the output gap, and that it is using the short-term interest rate as the instrument of monetary policy. Most central banks would not characterize their behavior in this way. However, the reason for the popularity of this kind of monetary policy rule is that it provides a good simple empirical representation of central bank behavior under a wide variety of monetary policy regimes. For example, the conventional view of the pre-ECB Bundesbank is that it targeted monetary aggregates. However, Clarida and Gertler (1997) and Clarida, Gali and Gertler (1998) argue that a forward looking Taylor rule provides a better empirical representation of the Bundesbank's actual behavior. Specifically, if the above Taylor rule is augmented 
by the deviation of the money supply from its target, Clarida, Gali and Gertler find that the coefficients on inflation and the output gap are almost unchanged while the coefficient on the money supply is small.

The ECB represents its policy as being a hybrid of inflation targeting and monetary targeting, though Svensson $(1999,2000)$ argues that inflation forecasts are in fact the key factor in policy decisions. In this paper, we therefore represent monetary policy by the above forward-looking Taylor rule.

Estimation of the forward-looking Taylor rule is straightforward. The monetary policy rule can be written in the form

$$
i_{t}=\rho i_{t-1}+(1-\rho) \alpha+(1-\rho) \beta \pi_{t+n}+(1-\rho) \gamma y_{t}+v_{t}
$$

where $v_{t}=\varepsilon_{t}+(1-\rho) \beta u_{t+n}^{\pi}+(1-\rho) \gamma u_{t}^{y}, u_{t+n}^{\pi}=\pi_{t+n}-E_{t}\left(\pi_{t+n}\right)$ and $u_{t}^{y}=y_{t}-E_{t}\left(y_{t}\right)$. This equation relates the interest rate to observable data and a composite error term, $v_{t}$. The composite error term is uncorrelated with any variables in the information set at time $t$. The equation can therefore be estimated by instrumental variables, using any variables in the information set at time $t$ as instruments. Estimates of the structural parameters $\rho, \alpha, \beta$ and $\gamma$ can be recovered directly, with standard errors constructed by the delta method.

We estimate this forward-looking Taylor rule using monthly German data, covering the period 1985:01 to 1998:12, prior to the launch of the euro. We consider a one-year ahead rule $(n=12)$ and use 6 lags of the interest rate, inflation and the 
output gap as instruments. The data are all taken from the OECD's Main Economic Indicators, which splices West German data onto unified Germany data, in 1991. Following Clarida and Gertler (1997) and Clarida, Gali and Gertler (1998), the interest rate is the Frankfurt call money "day-to-day" interest rate ${ }^{1}$, inflation is the 12 -month growth rate of the CPI. The output gap is measured by the percent deviation of log industrial production from a quadratic trend. ${ }^{2}$ The output gap constructed in this way is shown in Figure 1. Our estimation period starts in January 1985, because the euro area industrial production data that we use only goes back this far, and we want the output gap to be constructed by detrending industrial production over the same time period throughout the paper.

The parameter estimates (Table 1) are very close to those obtained by Clarida, Gali and Gertler. Specifically, the coefficient on inflation is somewhat greater than 1, the coefficient on the output gap is small but positive and the degree of interest rate smoothing is high. The parameter estimates are also quite similar to those that are estimated for the Federal Reserve, in the Volker-Greenspan era, by Clarida, Gali and Gertler, and others.

\footnotetext{
${ }^{1}$ They choose this interest rate on the grounds that it was the focus of the Bundesbank's reserve management policy.

${ }^{2}$ Results using log-linear detrending are virtually identical. The effect of possible measurement error in the output gap is discussed in section 3
} 


\section{Euro interest rates and the Bundesbank's Taylor Rule}

It will be some years before there is enough data to properly estimate a monetary policy rule for the ECB. The following counterfactual experiment sheds some light on ECB behavior, however. We compute the target interest rate implied by the Bundesbank monetary policy rule in Table 1 using euro area data since January 1999. The euro area data consist of area-wide industrial production and harmonized CPI, obtained from the ECB, with the Frankfurt overnight rate continuing to be used as the short-term interest rate. The industrial production series goes back to January 1985 and was log-quadratically detrended to obtain an output gap series (Figure 1).

The fitted target and actual interest rates are shown in Figure 2. Note that this figure plots the fitted target rate, $i_{t}^{*}$, not the fitted interest rate, $i_{t}$. This is standard to the literature on monetary policy rules: because of the high degree of interest rate smoothing, the latter is always very close to the actual interest rate. Because the monetary policy rule is forward-looking and the fitted target interest rate is computed using the actual realized inflation rate, the fitted target rate can only be computed through February 2000 using our data which go through February 2001.

The fitted target interest rate is generally quite close to the actual interest rate. The primary exceptions are in the early 1990s and the period since the launch of the

euro. The low rate relative to target in the early 1990s has been attributed to the Bundesbank trying to accommodate the problems caused by reunification. 
The large gap that opened up between the actual and fitted target interest rates shortly before the launch of the euro has continued to get wider until the end of the sample. ${ }^{3}$ Inflation was rising sharply over this period and the Bundesbank's reaction function (with its high weight on inflation relative to its weight on the output gap) would have called for a sharp tightening of monetary policy. Instead interest rates were lowered in 1998 and at the beginning of 1999 and raised only slightly thereafter. In February 2000, the actual overnight interest rate was $3.27 \%$, but the estimated Bundesbank reaction function would have prescribed a target interest rate of $6.47 \%$. On average over the period, the target exceeds the actual by 294 basis points.

Alesina et al. (2001) and Gali (2001) also compare the monetary policy of the ECB with a benchmark monetary policy rule, and find that euro area interest rates are generally lower than the monetary policy rule would predict. We find a larger discrepancy between actual and target rates than they do. ${ }^{4}$

There are several possible explanations for the relatively low euro interest rates including:

1. Variables other than the output gap and forecast inflation may enter into the

\footnotetext{
${ }^{3}$ The euro was launched in January 1999, but it is interesting to note that this large gap began about one year earlier.

${ }^{4}$ In part, our discrepancy is larger because they impose a zero coefficient on the output gap. We estimate a small positive coefficient on the gap, which combined with the positive and growing euro area output gap over the last two years raises our estimated target rate.
} 
monetary policy rule. Possible examples might include the deviation of money supply from its target, the exchange rate, or the U.S. Federal Funds rate.

2. In our empirical work, we use the headline (harmonized) consumer price index to measure inflation. Recently, core inflation has been substantially lower than the headline figure, particularly due to the surge in energy prices, and it is not clear $a$ priori which inflation measure is more relevant for our purposes. Agents often use headline inflation in key economic decisions such as wage negotiations. On the other hand, there may be high-frequency variation in headline inflation, say due to energy prices, that the monetary authorities may wish to ignore.

3. We are using ex-post realized inflation to fit the target interest rate, rather than the ex-ante forecast of inflation upon which the central banks make decisions.

4. The ECB may be using a backward-looking monetary policy rule, rather than the forward-looking rule we have specified.

5. The true output gap may be lower than our estimate.

6. In recent years, different euro area economies have had very different inflation rates. Headline inflation for the year 2000 ranged from 1.8\% in France to 5.3\% in Ireland. One possible interpretation of the low euro area interest rates is that the ECB is setting monetary policy with reference to the macroeconomic conditions in France and Germany, where inflation has been below average, rather than with reference to euro area aggregates. 
We consider these possibilities in turn. We conclude that while some of these issues may account for part of the gap between the actual and fitted target interest rates, they do not plausibly account for the entire gap.

Argument 1 states that we have omitted relevant variables such as the money supply or exchange rate from the policy rule. Clarida, Gali and Gertler (1998) augment the Bundesbank Taylor rule they estimate with a number of variables including the deviation of money supply from its target, the exchange rate and the US Federal Funds rate. They find that these additional variables are either statistically insignificant or at least are not economically very important. Even if these variables were relevant, if the sign of their effects is as commonly assumed, their inclusion would tend to push the target interest rate up: the euro area money supply is growing at a rate faster than the $4.5 \%$ reference rate, the foreign exchange value of the euro is weak, and prior to 2001 euro interest rates were well below the US Federal Funds rate. Therefore these factors could not plausibly account for the low euro area interest rates.

Arguments 2-4 are related. Instead of using ex post forward-looking headline inflation in constructing our baseline target rate, these arguments suggest using core inflation (2), and forecast inflation, instead of ex post (3) or backward-looking (4) inflation. Since our estimated coefficient on inflation, $\beta$, is 1.31, closing the average 294 basis point discrepancy between target and actual interest rates would require shift- 
ing the inflation measure used in constructing the target down by about 2 percentage points.

Since the inception of the euro, the difference between core and headline inflation has averaged 107 basis points. Multiplying by the $\beta$ parameter implies that switching to core from headline inflation would account for 140 basis points of the 294 basis point discrepancy.

To investigate 3 , we solve for the forecast inflation rate that would set the actual interest rate equal to the target interest rate, $\frac{i_{t}-\alpha-\gamma y_{t}}{\beta}$. The implied forecast yearahead inflation rate for each month from January 1999 to February 2001 is negative in several months and never rises above $1.25 \%$ (Table 2). We argue that these are unreasonably low. For example, in December 2000, the implied forecast for inflation is $0.75 \%$. In that month, the ECB published its own macroeconomic projections, ${ }^{5}$ forecasting 2001 harmonized CPI inflation at 2.3\% and 2001 GDP deflator inflation at $2.1 \%{ }^{6}$ The implied forecasts for inflation in Table 2 seem to be well below any reasonable forecasts for any inflation measure, for this and other months.

Indeed, it would be difficult to believe that the ECB forecasted lower inflation over this period than the forecast implied by the random walk assumption that inflation would be unchanged from its previous value. Using this worst case assumption,

\footnotetext{
${ }^{5}$ December 2000 is the first time that the ECB published its own macroeconomic projections.

${ }^{6}$ The reported forecasts are the midpoints of the ranges reported by the ECB in its December 2000 Monthly Bulletin.
} 
the forecast and backward looking arguments, (3) and (4), have the same practical implication. Using headline inflation, switching from our ex post proxy for forecasted inflation to the use of lagged inflation could account for 40 basis points of the 294 basis point discrepancy. Combining arguments $2-4$ we find that switching from ex post headline inflation to lagged core inflation would lower our average target rate by 180 basis points, leaving about one-third of the discrepancy.

We find this backward looking behavior implausible, however. A backward looking rule is inconsistent with how most central banks including the ECB claim to operate. Clarida, Gali and Gertler augment the baseline Taylor rule that they estimate for the Bundesbank with lagged inflation, so as to nest a backward looking monetary policy reaction function. They find that the effect of lagged inflation is not statistically significant, casting doubt on the backward looking view.

As for possible mis-measurement in the output gap, argument (5), our conclusions are similar. Taking as given the relatively low weight of 0.18 on the output gap in the Bundesbank's reaction function, the "true" euro area gap would have to be more than 15 percentage points lower than our estimate to explain the discrepancy in interest rates during the simulation period. ${ }^{7}$

We now turn to the possibility raised in (6) that ECB behavior is not driven by euro aggregates alone, but is instead more geared toward specific individual country

\footnotetext{
${ }^{7}$ Our output gap is about 1.5 percentage points above that estimated by the OECD for 1999 .
} 
performances. Specifically, we consider the effect of changing the country weights implicit in our use of euro area aggregates in calculating the baseline path for the target interest rate. We calculated the fitted target rate using the Bundesbank estimated monetary policy reaction function but using the inflation and output gap data for each euro area country from January 1999-February $2000 .^{8}$ The divergence in the fitted target rates across these economies is very large (Table 3). The fitted target rate consistently exceeds the actual interest rate for every euro area economy. In some months, the fitted target rate for Ireland exceeds 10 percent. On average the country specific target rate exceeds the actual by between 231 basis points for France and 644 basis points for Ireland.

The discrepancy between country-specific target and actual is relatively small for Germany and France. Thus, one could go some distance to explaining ECB policy by arguing that the these countries get excess weight in ECB deliberations. Even placing exclusive weight on these countries would leave a substantial gap, however, as the average discrepancy between target and actual for these two countries is 245 basis points, only about 50 basis points smaller than the euro-wide target.

It is difficult to imagine that the ECB would place extraordinary weight on

\footnotetext{
${ }^{8}$ The definitions for each country are as before: inflation is the growth rate of the harmonized CPI and the output gap uses industrial production with log-quadratic detrending, with the data taken from Main Economic Indicators. We exclude Greece, as it only became a member of the euro area in January 2001. Also we do not report results for Luxembourg.
} 
conditions in France and Germany. As Alesina et al. (2001) argue, while these countries have just under half the population in the euro area, the governing council of the ECB consists of one member per country plus six members of the Executive Board. Given this voting structure, it is more plausible that France and Germany get less weight than implied in our area-wide target rate. The area-wide target is based on euro aggregates in which Germany and France receive a weight of over one-half. To show the potential importance of a weighting scheme closer to the voting weights we did the following simple (if somewhat whimsical) exercise. Suppose that member countries use the estimated Bundesbank reaction function, but consider only their own country data. Thus, they prefer the rate closest to the country-specific rate in Table 3. A naive median voter result implies that the median country-specific rate would prevail each period. The interest rate selected in this way is between 16 and 57 basis points higher still than is the interest rate using the Bundesbank's Taylor rule and euro-wide aggregates.

Overall, issue (1) arguably provides no help explaining the 294 basis point average discrepancy and could make the problem worse. Core versus headline inflation, issue (2), could account for about half of the discrepancy. We argue that the case for a backward looking rule is weak, but going to backward looking inflation and core inflation could account for about $2 / 3$ of the discrepancy. The most plausible case is that the ECB is forward looking and that its inflation forecasts outperformed a 
random walk forecast over this period. Under this view, a large discrepancy remains.

A large discrepancy also remains when we take into account possible mismeasurement of the output gap, issue (5). Finally, if the ECB places almost exclusive emphasis on France and Germany in decision-making a bit more of the discrepancy would disappear, but such a weighting scheme is not very plausible. Indeed, taking account of voting weights might plausibly increase the discrepancy.

\section{Conclusion}

In this paper, we have estimated a standard monetary policy reaction function for the Bundesbank and have compared the ECBs actual monetary policy with the predictions from this reaction function, using euro area data. We find that interest rates have been consistently well below those predicted by the Bundesbank's estimated Taylor rule. We have considered a number of possible explanations, notably the discrepancy between core and headline inflation, errors in forecasting inflation and in our estimate of the output gap, and the possibility that monetary policy is being set with a different emphasis on particular countries than that which is implied by the use of euro area aggregates in a Taylor rule.

The magnitude of the discrepancy between the fitted target and actual interest rates is sufficiently large that it cannot plausibly be accounted for by any one

of these factors. Collectively, if one pushes each of these arguments further than we 
find plausible, they can account for most of the discrepancy. Under a more realistic view, a substantial discrepancy remains. This discrepancy is of the same magnitude as German rates in the early 1990s, when the Bundesbank was viewed as trying to accommodate the problems caused by reunification. This leaves the possible explanation that, the ECB has placed a relatively high weight on the output gap of the recently-created monetary union and relatively low weight on inflation, compared to the typical pre-ECB Bundesbank behavior.

\section{References}

Alesina, A., O. Blanchard, J. Gali, F. Giavazzi and H. Uhlig (2001): Defining a Macroeconomic Framework for the Euro Area, CEPR, London.

Clarida, R.and M. Gertler (1997): How the Bundesbank Conducts Monetary Policy in C. Romer and D. Romer (eds.) Reducing Inflation, University of Chicago Press, Chicago.

Clarida, R., J. Gali and M. Gertler (1998): Monetary Policy Rules in Practice: Some International Evidence, European Economic Review, 42, pp.1033-1067.

Clarida, R., J. Gali and M. Gertler (2000): Monetary Policy Rules and Macroeconomic Stability: Evidence and Some Theory, Quarterly Journal of Economics, 115, pp.147-180. 
DeGrauwe, P. (1997) The Economics of Monetary Integration, Oxford University Press, Oxford.

Gali, J. (2001): Monetary Policy in the Early Years of EMU, unpublished manuscript, Pompeu Fabra University.

Gros, D. and N. Thygesen (1998) European Monetary Integration, Addison Wesley Longman, New York.

Henderson, D. and W.J. McKibbin (1993): A Comparison of Some Basic Monetary Policy Regimes for Open Economies: Implications of Different Degrees of Instrument Adjustment and Wage Persistence, Carnegie-Rochester Conference Series on Public Policy, 39, pp.221-318.

Judd, J.P. and G.D. Rudebusch (1998): Taylor's Rule and the Fed: 1970-1997, Federal Reserve Bank of San Francisco Economic Review, 3, pp.3-16.

Svensson, L.E.O. (2000): The First Year of the Eurosystem: Inflation Targeting or Not?, American Economic Review, 90, pp.95-99.

Taylor, J.B. (1993): Discretion versus Policy Rules in Practice, Carnegie-Rochester Conference Series on Public Policy, 39, pp.195-214.

von Hagen, J. and R. Suppel (1994): Central Bank Constitutions for Federal Monetary Unions, European Economic Review, 38, pp.774-782. 
Table 1: Bundesbank Estimated Reaction Function

\begin{tabular}{ll}
\hline \hline$\alpha$ & $\begin{array}{l}2.58 \\
(0.85)\end{array}$ \\
$\beta$ & 1.31 \\
& $(0.35)$ \\
$\gamma$ & 0.18 \\
& $(0.16)$ \\
$\rho$ & 0.91 \\
& $(0.03)$ \\
\hline \hline
\end{tabular}

Table 2: Inflation forecast that equates actual and fitted target interest rates

\begin{tabular}{llll}
\hline \hline 1999:01 & 0.38 & $2000: 02$ & 0.12 \\
$1999: 02$ & 0.63 & $2000: 03$ & 0.32 \\
1999:03 & 0.37 & $2000: 04$ & 0.50 \\
1999:04 & 0.23 & $2000: 05$ & 0.44 \\
1999:05 & 0.14 & $2000: 06$ & 1.00 \\
$1999: 06$ & -0.01 & $2000: 07$ & 0.88 \\
$1999: 07$ & -0.07 & $2000: 08$ & 0.71 \\
$1999: 08$ & -0.23 & $2000: 09$ & 1.06 \\
1999:09 & -0.24 & $2000: 10$ & 1.25 \\
$1999: 10$ & -0.27 & $2000: 11$ & 1.14 \\
$1999: 11$ & -0.01 & $2000: 12$ & 0.75 \\
$1999: 12$ & 0.20 & $2001: 01$ & 1.02 \\
$2000: 01$ & 0.21 & $2001: 02$ & 1.09 \\
\hline \hline
\end{tabular}


Table 3: Fitted target interest rates using individual country inflation and output gap data

\begin{tabular}{|c|c|c|c|c|c|c|c|c|c|c|c|c|}
\hline & France & FRG & Italy & Spain & Belgium & NLD & Austria & Finland & Ireland & Portugal & EuroWide & Actual \\
\hline 99:01 & 4.85 & 4.95 & 5.34 & 6.73 & 3.38 & 4.61 & 3.79 & 6.07 & 9.36 & 5.51 & 5.18 & 3.14 \\
\hline 99:02 & 4.57 & 4.95 & 5.29 & 6.46 & 4.31 & 4.59 & 4.66 & 6.44 & 9.32 & 5.13 & 4.94 & 3.11 \\
\hline 99:03 & 4.81 & 4.94 & 5.78 & 6.57 & 5.39 & 4.71 & 4.88 & 6.66 & 8.79 & 4.98 & 5.22 & 2.93 \\
\hline 99:04 & 4.32 & 4.39 & 5.30 & 6.72 & 5.18 & 4.58 & 4.64 & 6.17 & 9.06 & 5.65 & 4.90 & 2.68 \\
\hline $99: 05$ & 4.74 & 4.31 & 5.18 & 6.83 & 5.38 & 5.18 & 4.62 & 5.72 & 9.08 & 6.25 & 4.88 & 2.55 \\
\hline 99:06 & 5.10 & 5.18 & 5.87 & 7.38 & 6.49 & 5.63 & 5.81 & 6.30 & 9.65 & 6.85 & 5.73 & 2.57 \\
\hline 99:07 & 5.38 & 5.24 & 5.93 & 7.80 & 4.93 & 6.48 & 5.10 & 6.06 & 10.61 & 7.39 & 5.75 & 2.51 \\
\hline 99:08 & 5.34 & 5.25 & 6.00 & 7.52 & 7.26 & 5.56 & 5.13 & 5.72 & 10.06 & 7.99 & 5.74 & 2.43 \\
\hline 99:09 & 5.93 & 6.10 & 5.91 & 7.88 & 8.01 & 6.19 & 5.94 & 6.68 & 10.39 & 7.41 & 6.37 & 2.42 \\
\hline $99: 10$ & 5.78 & 5.97 & 6.18 & 8.17 & 8.02 & 6.66 & 5.84 & 6.16 & 11.01 & 7.87 & 6.36 & 2.49 \\
\hline 99:11 & 6.06 & 6.25 & 6.54 & 8.33 & 8.04 & 6.38 & 6.98 & 6.16 & 10.49 & 8.08 & 6.69 & 2.92 \\
\hline $99: 12$ & 5.17 & 5.86 & 6.30 & 8.34 & 6.65 & 6.48 & 5.61 & 6.84 & 9.35 & 7.95 & 6.14 & 3.03 \\
\hline 00:01 & 4.59 & 5.62 & 6.08 & 7.98 & 6.04 & 7.87 & 5.49 & 6.42 & 5.45 & 8.53 & 5.87 & 3.03 \\
\hline 00:02 & 4.79 & 6.30 & 6.36 & 8.56 & 6.65 & 9.01 & 5.75 & 6.10 & 6.68 & 8.64 & 6.47 & 3.27 \\
\hline Discrep & 2.31 & 2.59 & 3.07 & 4.73 & 3.33 & 3.20 & 2.51 & 3.46 & 6.44 & 4.23 & 2.94 & \\
\hline
\end{tabular}

Note: Discrep is the average discrepancy between the target shown in the column and the actual rate that prevailed (i.e., the column average minus the average of the final column). 
Figure 1: Output Gaps for Germany and the Euro Area

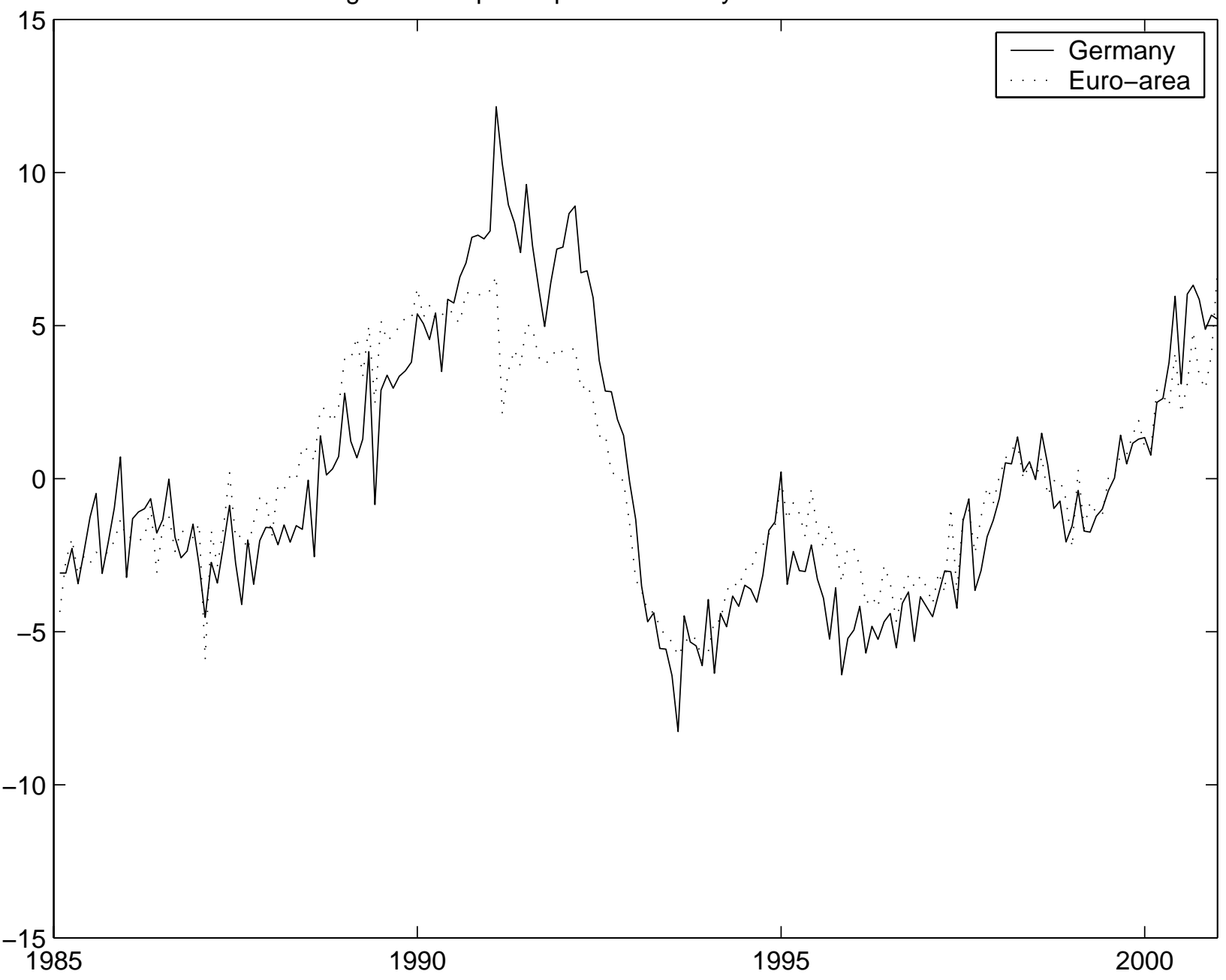


Figure 2: Forward looking Taylor rule

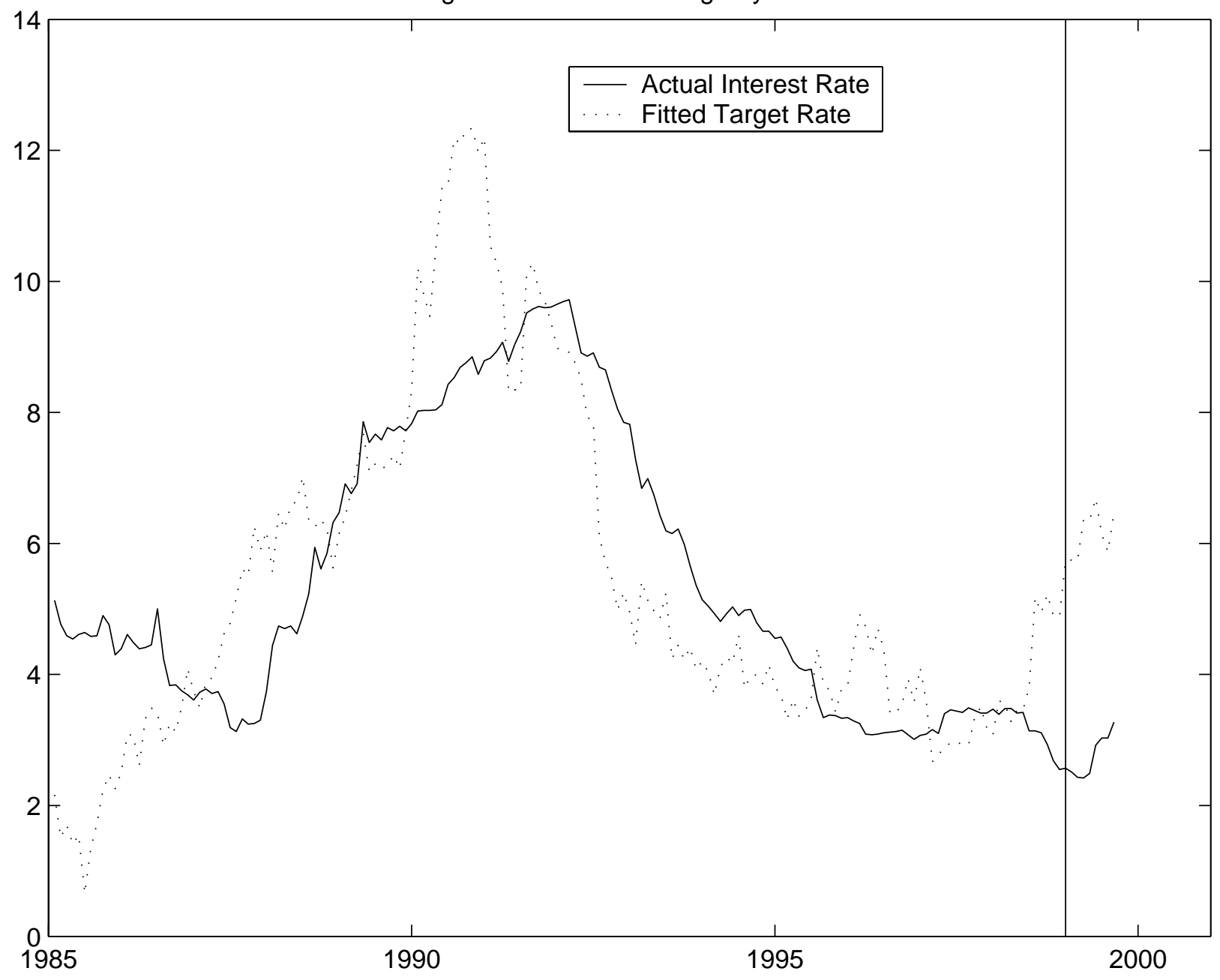

